\title{
SISTEM PENGAWASAN ASURANSI SYARIAH DALAM KAJIAN UNDANG-UNDANG NOMOR 40 TAHUN 2014 TENTANG PERASURANSIAN
}

\author{
Sukadi Suratman, Muhammad Junaidi \\ Magister Ilmu Hukum Universitas Semarang
}

\begin{abstract}
ABSTRAK
Tujuan penelitian ini adalah untuk menganalisa sistem penagwasan asuransi syariah berdasarkan undang-undang yang berlaku. Penerapan prinsip syariah dalam asuransi syariah bertolak dari ketentuan hukum Islam dalam aspek ekonomi syariah. Konsep asuransi syariah menggunakan berbagai risiko (risk sharing) yang berdeda dari konsepsi asuransi konvensional. Penerapan prinsip syariah dalam asuransi syariah inilah yang ditempatkan pada bagian pertama pengawasan. Metode yang digunakan dalam penelitian ini adalah penelitian yuridis normative. Banyak kendala yang dihadapi dalam pelaksanaan pengawasan pengawasan asuransi syariah diantaranya soal pemahaman masyarakat. Kendala lainnya yang cukup berpengaruh adalah dukungan penuh dari para pengambil kebijakan di negeri ini. Termasuk kendala dukungan pemerintah adalah upaya harmonisasi dan singkronisasi peraturan yang masih menjadi hambatan secara yuridis diantaranya persoalan. Upaya-upaya dalam mengatasi kendala tersebut dapat dilakukan melalui penguatan struktur. Struktur yang ada saat ini sudah baik, tetapi karena DSN-MUI menghadapi tugas dan tantangan yang lebih berat seperti mengurusi dan bermitra dengan lembaga-lembaga keuangan syariah yang notabene diurus oleh prktisi-praktisi yang professional. Disisi lain yang perlu diterjemahkan dalam praktinya sehingga memungkinkan sistem pengawasan berjalan maksimal adalah evaluasi kelembagaan pengawasan harus dijalankan secara keberlanjutan sehingga memungkinkan sistem pengawasan pada lembaga asuransi syariah utamanya yang dijalankn oleh lembaga Dewan Pengawas syariah dapat berjalan maksimal.
\end{abstract}

Keyword : Pengawasan; asuransi syariah; ekonomi syariah 


\title{
SHARIA INSURANCE SUPERVISION SYSTEM IN LAW NUMBER 40 OF 2014 CONCERNING INSURANCE
}

\author{
Sukadi Suratman, Muhammad Junaidi \\ Master of Law, University of Semarang
}

\begin{abstract}
The purpose of this study is to analyze the sharia insurance claim system based on applicable laws. The application of sharia principles in sharia insurance is based on the provisions of Islamic law in sharia economic aspects. The concept of Islamic insurance uses a variety of risks (risk sharing) which is different from the conventional insurance conception. The application of sharia principles in sharia insurance is placed in the first part of supervision. The method used in this research is normative juridical research. Many obstacles faced in the implementation of sharia insurance supervision oversight including a matter of public understanding. Another obstacle that is quite influential is the full support of policy makers in this country. Including the obstacles of government support are efforts to harmonize and synchronize regulations which are still juridical obstacles including issues. Efforts to overcome these obstacles can be done through strengthening the structure. The current structure is already good, but because DSN-MUI faces heavier tasks and challenges such as taking care of and partnering with Islamic financial institutions which are in fact managed by professional practitioners. On the other hand that needs to be translated into practice so as to enable the oversight system to run optimally, the institutional evaluation of supervision must be carried out in a sustainable manner so as to enable the supervision system in the main sharia insurance institutions run by the Sharia Supervisory Board to run optimally.
\end{abstract}

Keyword: Oversight; Islamic insurance; Islamic economics 


\section{A. PENDAHULUAN}

Asuransi sebagai salah satu lembaga keuangan bukan bank yang mempunyai peranan tidak jauh berbeda dari bank, yaitu bergerak dalam bidang layanan jasa yang diberikan kepada masyarakat dalam mengatasi risiko yang di masa yang akan datang melalui pembayaran premi. Premi yang dibayarkan dimanfaatkan untuk pelaksanaan pembangunan, salah satunya sumber modal pembangunan. Asuransi juga mempunyai peranan lain berkaitan dengan masalah risiko, dan risiko ini berhubungan dengan asuransi sebagai lembaga pengalihan dan pembagian risiko, yang mempunyai kegunaan positif bagi Negara.

Faedah yang diberikan oleh usaha perasuransian antara lain, membantu masyarakat dalam rangka mengatasi segala risiko yang dihadapinya. Asuransi akan memberikan ketenangan dan kepercayaan diri yang lebih tinggi kepada yang bersangkutan. Asuransi juga merupakan sarana masyarakat atau institusi-institusi lain, atas kemungkinan memderita kerugian lebih lanjut karena terjadinya suatu peristiwa yang tidak tertentu atau belum pasti. Asuransi dapat pula memberikan rasa aman bagi anggota masyarakat. Dapat dikatakan kehadiran asuransi dalam masyarakat itu jauh lebih bermanfaat bagi semua pihak dibandingkan dengan ketidakhadirannya. ${ }^{1}$

Seiring perkembangan asuransi di Indonesia yang cukup pesat, menunjukkan kesadaran masyarakat akan pentinganya asuransi kian meningkat. Seperti yang dilansir di berita online kompas.com, menurut Kepala Departemen Komunikasi Asuransi Jiwa Indonesia (AAJI) Nini Sumohandoyo, pertumbuhan tertanggung individu sebesar 13,8 persen meningkat menjadi 15, 5 juta orang diakhir 2014, dibanding tahun 2013 sebesar 13, 62 juta orang. ${ }^{2}$ Peningkatan ini adalah pertanda baik bagi bisnis asuransi bahwa masyarakat menyadari pentingnya asuransi tidak hanya sebagai suatu investasi namun juga melalui asuransi, baik asuransi konvensional maupun asuransi syariah.

1 Sri Rejeki Hartono, 2008. Hukum Asuransi dan Perusahaan Asuransi, Sinar Grafika, Jakarta.hlm.7

2 "Kesadaran akan Asuransi Kian Meningkat" http://bisniskeuangan.kompas.com.

Kesadaran.Akan.Asuransi.Kian.Meningkat., diakses 11 Oktober 2017, jam 11.11 WIB 
Asuransi syariah merupakan prinsip perjanjian berdasarkan hukum Islam antara perusahaan asuransi atau perusahaan reasuransi dengan pihak lain, dalam menerima amanah dalam mengelola dana peserta melalui kegitan investasi yang diselenggarakan sesuai dengan syariah. Lahirnya perusahaan asuransi syariah didukung dengan besarnya jumlah penduduk yang beragama Islam yang membutuhkan suatu lembaga keuangan Islami sehingga setiap interaksi muamalah yang dilakukan sesuai dengan syariah. Karena pada dasarnya masyarakat muslim memandang operasional asuransi konvensional dengan ragu-ragu, atau bahkan keyakinan bahwa praktek itu cacat dari sudut pandang syari'at. Asuransi syariah merupakan salah satu lembaga keuangan syariah yang dapat tumbuh dan berkembang dengan baik di Indonesia.

Pengertian Asuransi Syariah dalam Pasal 1 angka 1 Undang-Undang Nomor 40 Tahun 2014 tentang Perasuransian, yaitu: “ Asuransi Syariah adalah kumpulan perjanjian, yang terdiri atas perjanjian antara perusahaan Asuransi Syraiah dan pemegang polis dan perjanjian di antara para pemegang polis, dalam rangka pengelolaan kontribusi berdasarkan prinsip syariah guna saling tolong menolong dan melindungi dengan cara:

a. memberikan penggantian kepada Peserta atau pemegang polis karena kerugian, kerusakan, biaya yang timbul, kehilangan keuntungan, atau tanggung jawab hukum kepada pihak ketiga yang mungkin diderita Peserta atau pemegang polis karena terjadinya suatu peristiwa yang tidak pasti; atau

b. memberikan pembayaran yang didasarkan pada meninggalnya Peserta atau pembayaran yang didasarkan pada hidupnya Peserta dengan manfaat yang besarnya telah ditetapkan dan/atau didasarkan pada hasil pengelolaan dana. ${ }^{3}$

Di antara Asuransi Syariah dalam Undang-Undang Nomor 40 Tahun 2014 tentang Perasuransian merupakan langkah pemerintah agar dapat mengembangkan Asuransi Syariah pula. Terdapat perbedaan antara Asuransi Konvensional dan Asuransi Syariah yang diatur dalam Undang-Undang Nomor 40 Tahun 2014 tentang Perasuransian. Perbedaan tersebut karena Asuransi Syariah menggunakan

\footnotetext{
${ }^{3}$ UU No. 40 Tahun 2014 tentang Perasuransian (Pasal 1)
} 
prinsip syariah. Penyempurnaan terhadap peraturan perundang-undangan mengenai perasuransian harus dilakukan untuk meciptakan industri perasuransian yang lebih sehat, dapat diandalkan, amanah, dan kompetitif serta meningkatnya perannya dalam mendorong pembangunan nasional. ${ }^{4}$ Dalam asuransi Islam terdapat akad yang dilakukan sebagai landasan untuk menjalankan prinsip syariah, agar terhindar dari unsur riba, spekulasi, kecurangan dan ketidak jelasan, sehingga masyarakat tidak ragu untuk melakukan kegiatan pada perusahaan asuransi syariah, dengan demikian bagaimana akad yang dilakukan pada perusahaan syariah.

Badan Arbitrase Syariah Nasional (Basyarnas) adalah sebuah wadah alternatif diluar pengadilan (non-litigasi) di dalam penyelesaian sengketa atau perkara di perbankan syariah dan Lembaga Keuangan Syariah (LKS) lainnya. Keberadaan Basyarnas saat ini sangat dibutuhkan oleh umat Islam Indonesia, terlebih dengan semakin marak dan berkembangnya perusahaan perbankan dan keuangan syariah di Indonesia dewasa ini. Pertumbuhan ekonomi dan bisnis syariah yang pesat dan kompleks seperti saat ini pasti melahirkan berbagai macam bentuk kerjasama atau transaksi bisnis. ${ }^{5}$

Asuransi dalam Islam dikenal dengan istilah tafakul yang berarti saling memikul resiko di antara sesama orang, sehingga antara satu dengan yang lainnya menjadi penanggung atas risiko yang lainnya. Saling pikul risiko ini dilakukan atas dasar tolong-menolong dalam kebaikan di mana masing-masing mengeluarkan dana/ sumbangan/ derma (tabarru' ) yang ditunjuk untuk menanggung risiko tersebut. Pada tanggal 17 Oktober 2014, pemerintah mengesahkan Undang-Undang Nomor 40 Tahun 2014 tentang Perasuransian kepada pelaku industri perasuransian di Indonesia, untuk menggantikan Undang-Undang Nomor 2 Tahun 1992 tentang Usaha Perasuransian. Dengan diterbitkannya Undang-Undang Nomor 40 Tahun 2014 tentang Perasuransian ini diharapkan agar penyelenggaraan usaha

\footnotetext{
${ }^{4}$ Bagya Agung Prabowo dan Jasri Bin Jamal, 2016. Peranan Dewan Pengawas Syariah terhadap Praktik Kepatuhan Syariah dalam Perbankan Syariah di Indonesia, Jurnal Hukum IUS QUIA IUSTUM NO. 1 VOL. 24 JANUARI 2017, hal 13-129.

DOI: https://doi.org/10.20885/iustum.vol24.iss1.art6

${ }^{5}$ Ephin Apriyandanu, Kedudukan Basyarnas Dalam Penanganan Kepailitan Perbankan Syariah Ditinjau Dari UUNo. 21 Tahun 2008 Tentang Perbankan Syariah, Jurnal USM Law review Vol 1 No 1, Magister Hukum Universitas Semarang, Semarang, hal 33.
} 
perasuransian dapat berjalan dengan lebih baik dan perlindungan kepentingan masyarakat pengguna jasa asuransi dapat semakin ditingkatkan. ${ }^{6}$

Berlakunya Undang-Undang Nomor 40 Tahun 2014 tentang Perasuransian mengubah peta regulasi industry asuransi di Indonesia. Undang-undang ini secara tegas mengatur keberadaan asuransi syariah berdampingan dengan asuransi konvensional. Dengan demikian, eksistensi asuransi syariah sebagai alternatif asuransi yang dapat dipilih oleh masyarakat telah mempunyai landasan hukum, walaupun belum dirasakan optimal mengingat pengaturan asuransi syariah belum terintegrasi dalam suatu perundang-undangan yang khusus mengatur tentang asuransi syariah, sebagaimana halnya regulasi perbankan syariah. Salah satu substansi dalam Undang-Undang Nomor 40 Tahun 2014 BabXIII adalah tentang Peraturan dan Pengawasan. Pasal 57 menyebutkan bahwa pengaturan dan pengawasan kegiatan Usaha Perasuransian dilakukan oleh Otoritas Jasa Keuangan (OJK).

Tata cara operasional asuransi sudah ada ketentuan dalam Undang-Undang Republik Indonesia Nomor 40 Tahun 2014 dan ada DPS (Dewan Pengawas Syariah) untuk mengawasi kegiatan usaha asuransi syariah, dan fatwa-fatwa DSN (Dewan Syariah Nasional) sebagai pedoman kegiatan asuransi syariah yang harus sesuai dengan fatwa DSN-MUI dengan No.:12/DNS-MUI/X/2001 tentang pedoman umum pada asuransi syariah. ${ }^{7}$ Keberadaan asuransi syariah tidak lepas dari pengawasan Dewan Syariah Nasional Majelis Ulama Indonesia (DSN-MUI) sebagai bentuk menjaga kehalalan produk seiring dengan beragamnya produkproduk asuransi syariah yang ditawarkan oleh perusahaan asuransi. Kehalalan produk asuransi syariah dapat dilihat pada penerapan akad yang digunakan dalam polis asuransi. Penerapan akad dalam polis asuransi harus sesuai dengan yang dikeluarkan oleh Dewan Syariah Nasional Majelis Ulama Indonesia sebagai tolak ukur kesesuain dengan prinsip Islam.

\footnotetext{
${ }^{6}$ Suisno, Tinjauan Yuridis Tindak Pelanggaran Usaha Perasuransian Menurut Undang-Undang Nomor 40 Tahun 2014 tentang Perasuransian, Jurnal Independent Vol. 3 No. 1, Universitas Islam Lamongan, 2015, Lamongan. DOI: https://doi.org/10.30736/ji.v3i1.32

7 Gemala Dewi,2007, Aspek-Aspek Hukum Dalam Perbankan Dan Perasuransian Syariah Indonesia, Jakarta, Kencana Prenada Media Grup, hlm. 136
} 
Asuransi syariah sebagai kegiatan perasuransian berdasarkan pada prinsip syariah, tentunya perihal prinsip syariah ini menjadi landasan hukum utamanya yang kemudian tercakup ke dalam pengaturan menurut Undang-Undang No. 40 Tahun 2014 berkenaan dengan penyelesaian sengketa perasuransian syariah menurut Pasal 54 ayat (1) Undang-Undang No. 40 Tahun 2014, dinyatakan bahwa: "Perusahaan asuransi, perusahaan asuransi syariah, perusahaan reasuransi, dan perusahaan reasuransi syariah dan pemegang polis, tertanggung, peserta, atau pihak lain yang berhak memperoleh manfaat asuransi". 8

Uraian tersebut telah menemukan konsepsi yang diinginkan oleh pembentuk peraturan perundang-undangan, bahwa asuransi syariah perlu dilakukan pengawasan. Pengawasan dilakukan oleh OJK dan DSN yang mengacu pada Undang-Undang Nomor 40 Tahun 2014 tentang Perasuransian. Pengawasan kegiatan usaha asuransi syariah dilakukan berdasarkan pada prinsip syariah yang tercakup dalam pengaturan menurut Undang-Undang No. 40 Tahun 2014 tentang perasuransian. Pengawasan secara etimology lughawi berarti riqabah makna lughawi penjagaan, penyelenggaraan dan pemantauan, sebagaimana firman Allah dalam surat An-Nisa ayat 1, Sesungguhnya Allah mengawasi kalian. Pengawasan dalam pengertian istilah syariah bermakna pemantauan (isyraf), pemeriksaan (muraja'ah) dan investigasi (fahsh) bertujuan untuk menjaga manfaat (mura'at maslahah) dan menghindari kehancuran (idra 'mafsadah). ${ }^{9}$

Istilah pengawasan menurut Kamus Besar Bahasa Indonesia (KBBI) berasal dari perkataan awas yang bermaksud memberi perhatian dilihat dengan baik, dalam arti melihat sesuatu dengan teliti dan menyeluruh, kegiatan yang tidak lebih daripada memberikan laporan berdasarkan realitas sesungguhnya apa yang diawasi. Sedangkan dalam bahasa Inggris disebut controlling diterjemahkan dengan istilah pengawasan dan pengendalian. Pengendalian berasal dari kendali, supaya

${ }^{8}$ Undang-Undang Nomor 40 Tahun 2014 tentang Perasuransian Pasal 54 ayat 1

${ }^{9}$ Bagya Agung Prabowo dan Jasri Bin Jamal, 2016, Peranan Dewan Pengawas Syariah terhadap Praktik Kepatuhan Syariahdalam Perbankan Syariah di Indonesia. Jurnal Hukum IUS QUIA IUSTUM NO. 1 VOL. 24 JANUARI 2017: 113-129 
membayangkan pengendalian langsung, kegiatan perbaikan yang salah dan meluruskan arah yang benar. ${ }^{10}$.

Fungsi dan peranan DPS pada asuransi syariah, memiliki hubungan yang kuat dengan pengurusan risiko asuransi. Penerapan prinsip syariah dalam asuransi syariah bertolak dari ketentuan hukum Islam dalam aspek ekonomi syariah. Konsep asuransi syariah menggunakan berbagai risiko (risk sharing) yang berdeda dari konsepsi asuransi konvensional. Penerapan prinsip syariah dalam asuransi syariah inilah yang ditempatkan pada bagian pertama pengawasan.

\section{B. PERMASALAHAN}

1. Bagaimana sistem pengawasan asuransi syariah berdasarkan Undang-Undang Nomor 40 Tahun 2014 tentang Perasuransian?

2. Bagaimana hambatan dalam pengawasan asuransi syariah berdasarkan UndangUndang Nomor 40 Tahun 2014 tentang Perasuransian dan solusinya?

\section{PEMBAHASAN}

\section{Sistem Pengawasan Asuransi Syariah Berdasarkan Undang-Undang Nomor 40 Tahun 2014 Tentang Perasuransian}

Berdasarkan hasil penelitian yang dilakukan di dapat hasil sebagai berikut:

a. Pengaturan Usaha Perasuransian yang dimuat dalam Undang-ndang Nomor 40 Tahun 2014 tentang Perasuransian, serta ditunjuknya Otoritas Jasa Keuangan (OJK) sebagai lembaga Negara yang memiliki kuasa penuh dalam menjalankan fungsi dan pengawasan diharapkan dapat membuat kebijakan terhadap perasuransian yang dapat membawa perasuransian menjadi lebih berkembang di masa depan dan dapat bersaing dengan Negara-negara maju dalam dunia asuransi.

b. Sanksi hukum terhadap pelaku tindak pelanggaran usaha perasuransian menurut Undang-Undang Nomor 40 Tahun 2014 tentang Perasuransian atas dasar hal tersebut maka pengaturan sanksi sangatlah jelas, jika usaha perasuransian melakukan pelanggaran terhadap ketentuan undang-undang atau peraturan dalam pelaksanaan maka Otoritas Jasa Keuangan (OJK)

\footnotetext{
10 Victor M.Situmorang, 2004, Aspek Hukum Pengawasan Melekat, Jakarta: Rineka Cipta,
} hlm. 21 
berwenang melakukan tindakan berupa pemberian peringatan, pembatasan kegiatan usaha, larangan untuk memasarkan produk asuransi, memberi sanksi-sanksi pidana hingga pada pencabutan ijin usaha.

Asuransi adalah perjanjian antara dua pihak, yaitu perusahaan asuransi dan pemegang polis, yang menjadi dasar bagi penerimaan premi oleh perusahaan asuransi sebagai imbalan untuk :

1. Memberikan penggantian kepada tertanggung atau penanggung polis karena kerugian, kerusakan, biaya yang timbul, kehilangan keuntungan, atau tanggung jawab hukum kepada pihak ketiga yang mungkin diderita tertanggung atau pemegang polis karena terjadinya sesuatu peristiwa yang tidak pasti; atau

2. Memberikan pembayaran yang didasarkan pada meninggalnya tertanggung atau pembayaran yang didasarkan pada hidupnya tertanggung dengan manfaat yang besarnya telah ditetapkan dan/atau didasarkan pada hasil pengelolaan dana. (UU No. 40 Tahun 2014 tentang Perasuransian, Pasal 1, ayat 1$)$.

Sedangkan menurut Undang-Undang Nomor 40 Tahun 2014 tentang Perasuransian, Pasal 1, ayat 2 yaitu :

Usaha perasuransian adalah segala usaha menyangkut jasa pertanggungan atau pengelolaan risiko, pertanggungan ulang risiko, pemasaran dan distribusi produk asuransi atau produk asuransi syariah atau penilaian kerugian asuransi atau asuransi syariah.

Berbicara mengenai tujuan asuransi yaitu meliputi tujuan pengalihan risiko, tujuan pembayaran ganti kerugian,tujuan pembayaran santunan, tujuan kesejahteraan anggota. Asuransi bagi masyarakat selain untuk memberikan kenyamanan, juga ada sisi lain yang ingin dicapai, yakni pemupukan dana bagi negara. Dana yang terkumpul dapat dipergunakan untuk biaya pembangunan nasional yang sedang dilaksanakan dalam berbagai sektor. Tampaknya di sinilah tantangan lembaga asuransi sebagai pengelola risiko yang dialihkan oleh masyarakat, yang tentunya ada biaya 
yang harus dikeluarkan oleh masyarakat yang lebih dikenal dengan premi, pihak asuransi harus memenuhi janjinya secara jujur.

Setiap Pihak yang melakukan Usaha Perasuransian wajib terlebih dahulu mendapatkan izin usaha dari Otoritas Jasa Keuangan (OJK). Berdasarkan Undang-Undang No. 40 Tahun 2014 Pasal 8, Ayat 2, untuk mendapatkan izin usaha harus dipenuhi persyaratan mengenai:

a. Anggaran Dasar,

b. Susunan Organisasi,

c. Modal disetor,

d. Dana Jaminan, Kepemilikan,

e. Kelayakan dan kepatutan pemegang saham dan Pengendali,

f. Kemampuan dan kepatutan Direksi dan Dewan Komisaris, atau yang setara dengan Direksi dan Dewan Komisaris pada Badan Hukum berbentuk Koperasi atau Usaha Bersama sebagaimana dimaksud dalam Pasal 6 ayat (1) huruf c, Dewan Pengawas Syariah, Aktuaris Perusahaan, dan Auditor Internal,

g. Tenaga Ahli,

h. Kelayakan Rencana Kerja,

i. Kelayakan Sistem Manajemen Risiko,

j. Produk yang akan dipasarkan,

k. Perikatan terhadap pihak terafiliasi apabila ada dan kebijakan pengalihan sebagian fungsi dalam penyelenggaraan usaha,

1. Infrastruktur penyiapan dan penyampaian laporan kepada Otoritas Jasa Keuangan,

m. Konfirmasi dan otoritas Pengawas di negara asal pihak asing, dan

n. Hal lain- lain yang diperlukan untuk mendukung pertumbuhan usaha yang sehat.

Dalam pelaksanaan pembangunan dapat terjadi berbagai ragam dan jenis risiko yang perlu ditanggulangi oleh masyarakat, bahwa usaha perasuransian yang sehat merupakan salah satu upaya untuk menanggulangi risiko yang dihadapi anggota masyarakat sekaligus merupakan salah satu lembaga penghimpun dana masyarakat, sehingga memiliki kedudukan strategis dalam pembangunan dan kehidupan perekonomian, dalam memajukan kesejahteraan umum. Berikut ini adalah jenis-jenis dari usaha perasuransian :

1. Usaha Asuransi Umum

2. Usaha Asuransi Jiwa

3. Usaha Reasuransi 
4. Usaha Asuransi Umum

5. Usaha Asuransi Jiwa Syariah

6. Usaha Reasuransi Syariah

7. Usaha Pialang Asuransi

8. Usaha Pialang Reasuransi

9. Usaha Penilai Kerugian Asuransi

10. Perusahaan Perasuransian

11. Perusahaan Asuransi

12. Perusahaan Asuransi Syariah.

Undang-Undang Nomor 40 Tahun 2014 tentang Perasuransian menggantikan Undang-Undang Nomor 2 Tahun 1992 tentang Usaha Perasuransian. Secara umum, terdapat banyak perbedaan antara kedua undangundang tersebut. Banyak ketentuan di undang-undang asuransi yang baru yang sebelumnya tidak diatur oleh undang-undang asuransi yang lama. Dari segi subtansi, undang-undang asuransi yang baru mengatur lebih lengkap dibandingkan dengan undang-undang asuransi yang lama dilihat dari jumlah rumusan pasal dan jumlah bab yang tercantum. Namun demikian, perbedaan yang paling signifikan antara kedua undang-undang tersebut di atas adalah peralihan fungsi pengaturan dan pengawasan terhadap asuransi dari Menteri Keuangan kepada Otoritas Jasa Keuangan (OJK). OJK berfungsi menyelenggarakan sistem pengaturan dan pengawasan yang terintegrasi terhadap keseluruhan kegiatan di dalam sektor jasa keuangan. ${ }^{11}$ OJK melaksanakan tugas pengaturan dan pengawasan tersebut terhadap: (i) kegiatan jasa keuangan di sektor Perbankan; (ii) kegiatan jasa keuangan di sektor Pasar Modal; (iii) kegiatan jasa keuangan di sektor Perasuransian, Dana Pensiun, Lembaga Pembiayaan, dan Lembaga Jasa Keuangan lainya. ${ }^{12}$

Berdasarkan undang-undang, OJK resmi mengambil alih fungsi pengawasan perbankan dari Bank Indonesia sebagai bank sentral dan pengawasan sektor jasa keuangan non-perbankan dari Badan Pengawas Pasar Modal dan Lembaga Keuangan (Bapepam-LK). OJK berfungsi

${ }^{11}$ Indonesia, Undang-Undang Otoritas Jasa Keuangan, UU No. 21 Tahun 2011, LN No. 111, TLN No. 5253, Ps. 5.

12 Indonesia, Undang-Undang Otoritas Jasa Keuangan, UU No. 21 Tahun 2011, LN No.111, TLN No.5253, Ps.6. 
menyelenggarakan sistem pengaturan dan pengawasan yang terintregrasi terhadap keseluruhan kegiatan di dalam sektor jasa keuangan. ${ }^{13}$ OJK melaksanakan tugas pengaturan dan pengawasan tersebut terhadap: (i) kegitan jasa keuangan di sektor Perbankan; (ii) kegiatan jasa keuangan di sektor Pasar Modal; (iii) kegiatan jasa keuangandi sektor Perasuransian, Dana Pensiun, Lembaga Pembiayaan, dan Lembaga Jasa Keuangan lainnya. ${ }^{14}$

Berdasarkan undang-undang, OJK resmi mengambil alih fungsi pengawasan perbankan dari Bank Indonesia sebagai bank sentral dan pengawasan sektor jasa keuangan non-perbankan dari Badan Pengawas Pasar Modal dan Lembaga Keuangan (Bapepam-LK). Otoritas Jasa Keuangan diharapkan dapat membuat kebijakan pengaturan dan pengawasan terhadap perasuransian yang dapat membawa perasuransian menjadi lebih berkembang di masa depan dan dapat menyaingi negara-negara maju dalam hal asuransi.

Sesuai usaha perasuransian yang tidak mematuhi peraturan yang ditentukan dalam Undang-Undang Nomor 40 Tahun 2014 tentang Perasuransian, maka hal tersebut termasuk tindak pelanggaran. Yang termasuk kedalam unsur-unsur pelanggaran Usaha Perasuransian, yaitu:

1. Setiap Orang yang menjalankan kegiatan Usaha Asuransi, Usaha Asuransi Syariah, Usaha Reasuransi atau Usaha Reasuransi Syariah tanpa izin usaha sebagaimana dimaksud dalam Pasal 8 ayat (1).

2. Setiap Orang yang menjalankan kegiatan Usaha Pialang Asuransi atau Usaha Pialang Reasuransi tanpa izin usaha sebagaimana dimaksud dalam Pasal 8 ayat (1).

3. Setiap Orang yang melakukan kegiatan Usaha Penilaian Kerugian Asuransi tanpa izin usaha sebagaimana dalam Pasal 8 ayat (1).

4. Anggota Direksi, anggota Dewan Komisaris, atau yang setara dengan anggota Direksi dan anggota Dewan Komisaris pada badan hukum berbentuk Koperasi atau Usaha Bersama berdasarkan Pasal 6 ayat (1) huruf c, anggota Dewan Pengawas Syariah, Aktuaris Perusahaan, Auditor Internal, Pengendali, atau pegawai lain dari Perusahaan Perasuransian yang dengan sengaja memberikan laporan, informasi, data, dan/atau dokumen kepada Otoritas Jasa Keuangan sebagaimana dimaksud dalam Pasal 22 ayat (1) yang tidak benar, palsu, dan/atau menyesatkan.

${ }^{13}$ Indonesia, Undang-Undang Otoritas Jasa Keuangan, UU No. 21 Tahun 2011, LN No. 111, TLN No.5253, Ps. 5.

${ }^{14}$ Indonesia, Undang-Undang Otoritas Jasa Keuangan, UU No. 21 Tahun 2011, LN No.111, TLN No.5253, Ps. 6. 
5. Anggota Direksi, anggota Dewan Komisaris, atau yang setara dengan anggota Direksi dan anggota Dewan Komisaris pada badan hukum berbentuk Koperasi atau Usaha Bersama sebagaimana dimaksud dalam Pasal 6 ayat (10 huruf c, anggota Dewan Pengawas Syariah, Aktuarisasi Perusahaan, Auditor Internal, Pengendali atau pegawai lain dri Perusahaan Perasuransian yang dengan sengaja memberikan informasi, dari, dan/atau dokumen kepada pihak yang berkepentingan sebagaimana dimaksud dalam Pasal 22 ayat (a) dan Pasal 46 ayat (21) yang tidak benar, palsu, dan/atau menyesatkan.

6. Setiap Orang yang dengan sengaja tidak memberika informasi atau memberikan informasi yang tidak benar, palsu dan/atau menyesatkan kepada Pemegang Polis, Tertanggung, atau Peserta sebagaimana dimaksud dalam Pasal 31 ayat (2).

7. Setiap Orang yang menggelapkan Premi atau Kontribusi sebagaimana dimaksud dalam Pasal 28 ayat (5) dan Pasal 29 ayat (4).

8. Setiap Orang yang menggelapkan dengan cara mengalihkan, menjaminkan, mengagunkan, atau menggunakan kekayaan, atau menggunakan kekayaan, atau melakukan tindakan lain yang dapat mengurangi aset atau menurunkan nilai aset Perusahaan Asuransi, Perusahaan Asuransi Syariah, Perusahaan Reasuransi, atau Perusahaan Reasuransi Syariah sebagaimana dimaksud dalam Pasal 43 ayat (21).

9. Setiap Orang melakukan pemalsuan atas dokumen Perusahaan Asuransi, Perusahaan Asuransi Syariah, Perusahaan Reasuransi, atau Perusahaan Reasuransi Syariah, sebagaimana dimaksud dalam Pasal 33.

10. Anggota Direksi dan/atau pihak yang menandatangani polis baru dari Perusahaan Asuransi atau Perusahaan Asuransi Syariah yang sedang dalam pengenaan sanksi pembatasan kegiatan usaha sebagaimana dimaksud dalam Pasal 34.

11. Setiap Orang yang ditunjuk atau ditugasi oleh Otoritas Jasa Keuangan, yang menggunakan atau mengungkapkan informasi apapun yang bersifat rahasia kepada pihak lain, kecuali dalam rangka pelaksanaan fungsi, tugas, dan wewenangnya berdasarkan keputusan Otoritas Jasa Keuangan atau diwajibkan oleh undang-undang sebagaimana dimaksud dalam Pasal 67.

\section{Hambatan Dalam Pengawasan Asuransi Syariah Berdasarkan Undang-}

\section{Undang Nomor 40 Tahun 2014 Tentang Perasuransian Dan Solusinya}

Tantangan terbesar yang dihadapi oleh industri asuransi syariah bersumber pada dua hal utama yaitu permodalan dan sumber daya manusia. Tantangan-tantangan lain seperti masalah, ketidaktahuan masyarakat terhadap produk asuransi syariah, image dan lain sebagainya merupakan akibat dari dua masalah utama tersebut.

1. Minimnya modal 
Beberapa hal yang menjadi penyebab relative rendahnya penetrasi pasar asuransi syariah dalam sepuluh tahun terakhir adalah rendahnya dana yang memback up perusahaan asuransi syariah, promosi dan edukasi pasar yang relative belum dilakukan secara efektif (terkait dengan lemahnya dana), belum timbulnya industri penunjang asuransi syariah seperti broker-broker asuransi syariah, agen, adjuster, dan lain sebagainya, produk dan layanan belum diunggulkan diatas produk konvensional, posisi pasar yang masih ragu antara penerapan konsep syariah yang menyeluruh dengan kenyataan bisnis di lapangan yang terkadang sangat jauh dari prinsip syariah, dukungan kapasitas reasuransi yang masih terbatas (terkait juga dengan dana) dan belum adanya inovasi produk dan layanan yang benar-benar digali dari konsep dasar syariah.

2. Kurangnya SDM yang professional

Berdasarkan data Islamic Insurance Society (IIS) per Maret lalu, sekitar 80 persen dari seluruh cabang atau divisi asuransi syariah belum memiliki ajun ahli syariah. IIS mengestimasi asuransi syariah Indonesia per Maret lalu memiliki 200 cabang dan hanya didukung 30 ajun ahli syariah. Jumlah yang cukup sedikit bila dibandingkan kondisi SDM di asuransi konvensional. Per Maret lalu, sebagaian besar cabang asuransi konvensional telah memiliki sedikitnya seorang ajun ahli asuransi syariah. Jumlah tersebut sesuai dengan ketentuan Kementrian Keuangan

Upaya mendukung sistem pengawasan dalam kerangka penguatan sumber daya manusia sangat mendukung kepastian. Konsep kepastian hukum, dilihat dan perspektif sosiologis, semakin menjadi penting ketika hukum harus diletakkan dalam kerangka sistem sistem hukum modern. Sebagaimana diketahui, sistem hukum modern menunjuk pada sistem hukum yang dilahirkan dan tradisi pemikiran di Eropa Barat,khususnya sebagai implikasi dan Revolusi Perancis 1789. Ciri-ciri dan sistem hukum modern yang utama adalah: (a) Merupakan sistem hukum yang berasal dan tatanan sosial Eropa Barat pada Abad 19; (b) Sangat dipengaruhi paradigma positivisme dalam ilmu pengetahuan alam; (c) Rasional, lepas 
dan pengaruh Ketuhanan; (d) Meyakini bahwa hukum dapat dikonstruksi dan dikelola secara netral, tidak berpihak, impersonal, dan objektif; (e) Melindungi freedom-HAM; dan (f) Mendukung terciptanya kepastian untuk menjamin prediktabilitas ${ }^{15}$.

3. Ketidaktahuan Masyarakat Terhadap Produk Asuransi Syariah

Ketidaktahuan mengenai produk asuransi syariah dan mekanisme kerja merupakan kendala terbesar pertumbuan asuransi jiwa ini. Akibatnya, masyarakat tidak tertarik menggunakan asuransi syariah, dan lebih memilih jasa asuransi konvensional.

Konsekuensi atas ketidaktahuan masyarakat akan menjadi persoalan terhadap akses keadilan. Keadilan merupakan salah satu kebutuhan dalam hidup manusia yang umumnya diakui di semua tempat di dunia mi. Apabila keadi(an itu kemudian dikukuhkan ke dalam institusi yang namanya hukum, maka, seperti telah diuraikan di muka, institusi hukum itu harus mampu untuk menjadi saluran agar keadilan itu dapat diselenggarakan secara seksama dalam masyarakat. Beberapa ciri yang umumnya melekat pada institusi sebagai perlengkapan masyarakat yang demikian itu adalah:

a. Stabilitas

b. Merupakan pemberian kerangka social terhadap kebutuhan-kebutuhan dalam masyarakat

c. Sehubungan dengan institusi sebagai pengerangkaan secara social terhadap kebutuhan mansuai itu maka institusi menampilkan wujudnya dalam bentuk norma-norma

d. Jalinan antar institusi ${ }^{16}$

4. Dukungan Pemerintah Belum Memadahi

Meski sudah menunjukan eksistensinya, masih banyak kendala yang dihadapi bagi pengembangan ekonomi syariah di Indonesia. Soal pemahaman masyarakat hanya salah satunya. Kendala lainnya yang cukup berpengaruh adalah dukungan penuh dari para pengambil kebijakan di negeri ini, terutama menteri-menteri dan lembaga pemerintahan yang memiliki wewenang dalam menentukan kebijakan ekonomi. Termasuk

${ }^{15}$ Fx Adji Samekto, ibid, hlm 60

${ }^{16}$ Sadjipto Rahardjo, 1982, Ilmu Hukum, Alumni, Bandung, hlm 150-152 
kendala dukungan pemerintah adalah upaya harmonisasi dan singkronisasi peraturan yang masih menjadi hambatan secara yuridis.

Jika dukungan pemerintah belum optimal konsekwensi yang dihadapi adalah belum mampu mengakomodasi keadilan subtansi. Untuk mencapai suatu keadilan, disyaratkan sekaligus adanya unsur "keadilan yang substantif (justice)" (mengacu kepada hasil) dan unsur "keadilan prosedural" (fairness). Hal ini juga diamini oleh John Rawis sehingga muncul istilah terkenal darinya berupa justice as fairness, meskipun dan istilah "justice as fairness" tersebut mengandung arti bahwa unsur fairness mendapat prioritas tertentu dan segi metodologinya. Jika unsur fairness sudah tercapai, maka keadilan sudah terjadi. Di samping itu, Aristoteles juga berteori bahwa akan terjadi ketidakadilan distributif, manakala terjadi perlakuan yang tidak fair tentang distribusi manfaat (benefit) dan beban (burden). Perlakuan yang tidakfair tersebut kemudian populer dengan istilah "proteksi yang tidak sama" (unequal protection). Dalam konstitusi negara Amerika Serikat, perlindungan yang sama dipadukan secara apik dengan keadilan prosedural, melalui teori perlakuan yang sama (equalprotection) yang terdapat dalam amandemen ke-14 dan konstitusinya dengan teori keadilan prosedural (due process) dalam amandemen ke-5. Meskipun begitu, dalam perkembangannya istilah "due process" sendiri seben arnya bisa berarti "keadilan prosedural" (procedural dueprocess) dan juga "keadilan substantif" (substantive due process) $)^{17}$.

5. Image

Salah satu tantangan besar bisnis asuransi syariah di Indonesia dan negara lainnya, menurut Zein, adalah menyakinkan masyarakat akan keuntungan menggunakan asuransi syariah. "Perlu sekali mensosialisasikan asuransi syariah bukan saja berasal dari agama, tetapi memperlihatkan keuntungan.” Kenyataan di lapangan menunjukkan, bahwa para pelaku ekonomi syariah masih menghadapi tantangan berat untuk menanamkan

${ }^{17}$ Munir Fuady, ibid, hlm 116 
prinsip syariah sehingga mengakar kuat dalam perekonomian nasional dan umat Islamnya itu sendiri.

Dalam Undang-Undang Nomor 40 Tahun 2014 tentang Perasuransian Pasal 1 ayat 3 : Prinsip Syariah adalah prinsip hukum Islam dalam kegiatan perasuransian berdasarkan fatwa yang dikeluarkan oleh lembaga yang memilki kewenangan dalam penetapan fatwa di bidang syariah.

Dalam upaya pembinaan dan pengawasan kualitas syariah suatu lembaga keuangan syariah termasuk juga Asuransi Syariah dibentuklah DSN dan DPS. Dalam menjalankan tugasnya DSN-MUI paling tidak perlu melakukan pembenahan dalam dua hal yaitu :

\section{Restrukturisasi}

Struktur yang ada saat ini sudah baik, tetapi karena DSN-MUI menghadapi tugas dan tantangan yang lebih berat seperti mengurusi dan bermitra dengan lembaga-lembaga keuangan syariah yang notabene diurus oleh prktisi-praktisi yang professional. Karena itu, mitra kerjanya pun harus bisa mengimbangi secara professional. Badan pelaksana harian DSN perlu dipimpin oleh seorang eksekutif director yang diambil dari kalangan professional, digaji yang layak, yang benar-benar dengan fulltime.

Upaya restrukturisasi sangat sangat sinergi dengan pandangan Jimly Asshiddiqie yang menyebutkan bahwa paling tidak ada 11 prinsip pokok yang terkandung dalam negara hukum yang demok ratis, yakni: (i) adanya jaminan persamaan dan kesetaraan dalam kehidupan bersama; (ii) pengakuan dan penghormatan terhadap perbedaan/pluralitas; (iii) adanya aturan yang mengikat dan dijadikan sumber rujukan bersama; (iv) adanya mekanisme penyelesaian sengketa berdasarkan mekanisme aturan yang ditatati bersama itu; (v) pengakuan dan penghormatan terhadap HAM; (vi) pembatasan kekuasaan melalui mekanisme pemisahan dan pembagian kekuasaan disertai mekanisme penyelesaian sengketa ketatanegaraan antar lembaga negara baik secara vertikal maupun horizontal; (vii) adanya peradilan yang bersifat independen dan tidak memihak dengan kewibawaan putusan tertinggi atas dasar keadilan dan kebenaran; (viii) dibentuknya 
lembaga peradilan yang khusus untuk menjamin kedailan bagi warga negara yang dirugikan akibat putusan atau kebijakan pemerintahan (pejabat administrasi negara);(ix) adanya mekanisme 'judiciel review' oleh lembaga peradilan terhadap norma-norma ketentuan legislatif baik yang ditetapkan oleh lembaga legislatif maupun eksekutif; dan (xi) pengakuan terhadap asas legalitas atau 'due process of law' dalam keseluruhan sistem penyelengaraan negara ${ }^{18}$.

\section{Efektifitas Peran Evaluasi Sistem Pengawasan}

Evaluasi kelembagaan pengawasan harus dijalankan secara keberlanjutan sehingga memungkinkan sistem pengawasan pada lembaga asusransi syariah utamanya yang dijalankn oleh lembaga Dwan Pengawas syariah dapat berjalan maksimal.

Evaluasi yang demikian merupakan wujud dari keberlangsungan sistem hukum. Konsep kepastian hukum, dilihat dan perspektif sosiologis, semakin menjadi penting ketika hukum harus diletakkan dalam kerangka sistem sistem hukum modern. Sebagaimana diketahui, sistem hukum modern menunjuk pada sistem hukum yang dilahirkan dan tradisi pemikiran di Eropa Barat,khususnya sebagai implikasi dan Revolusi Perancis 1789. Ciriciri dan sistem hukum modern yang utama adalah: (a) Merupakan sistem hukum yang berasal dan tatanan sosial Eropa Barat pada Abad 19; (b) Sangat dipengaruhi paradigma positivisme dalam ilmu pengetahuan alam; (c) Rasional , lepas dan pengaruh Ketuhanan; (d) Meyakini bahwa hukum dapat dikonstruksi dan dikelola secara netral, tidak berpihak, impersonal, dan objektif; (e) Melindungi freedom-HAM; dan (f) Mendukung terciptanya kepastian untuk menjamin prediktabilitas ${ }^{19}$.

\section{Perubahan Peraturan Undang-Undang Nomor 40 Tahun 2014 tentang Perasuransian}

\footnotetext{
${ }^{18}$ Sirajuddin dan Winardi, 2015, Hukum Tata Negara Indonesia, Setara Press(Kelompok Instras Publising), Malang, hlm 282-283

${ }^{19}$ Fx Adji Samekto, ibid, hlm 60
} 
Seiring dengan kebutuhan bahwa peraturan harus mengakomodasi kebutuhan yang ada, maka sudah sebaiknya Undang-Undang Nomor 40 Tahun 2014 tentang Perasuransian harus ada penyesuaian. Upaya perubahan tersebut seiring perubahan keadilan subtantif. Hal lain yang penting juga adalah dalam ketentuan Undang-Undang Nomor 14 tahun 2014 kedudukan peraturan tersebut harus mengakomodasi sistem peraturan Otoritas Jasa Keuangan (OJK). Hal ini juga diharapkan peran antara dewan syariah nasional tidak berbenturan dengan peran otoritas jasa keuangan.

Untuk mencapai suatu keadilan, disyaratkan sekaligus adanya unsur “keadilan yang substantif (justice)” (mengacu kepada hasil) dan unsur "keadilan prosedural" (fairness). Hal ini juga diamini oleh John Rawis sehingga muncul istilah terkenal darinya berupa justice as fairness, meskipun dan istilah "justice as fairness" tersebut mengandung arti bahwa unsur fairness mendapat prioritas tertentu dan segi metodologinya. Jika unsur fairness sudah tercapai, maka keadilan sudah terjadi. Di samping itu, Aristoteles juga berteori bahwa akan terjadi ketidakadilan distributif, manakala terjadi perlakuan yang tidak fair tentang distribusi manfaat (benefit) dan beban (burden). Perlakuan yang tidakfair tersebut kemudian populer dengan istilah "proteksi yang tidak sama" (unequal protection). Dalam konstitusi negara Amerika Serikat, perlindungan yang sama dipadukan secara apik dengan keadilan prosedural, melalui teori perlakuan yang sama (equalprotection) yang terdapat dalam amandemen ke- 14 dan konstitusinya dengan teori keadilan prosedural (due process) dalam amandemen ke-5. Meskipun begitu, dalam perkembangannya istilah "due process" sendiri seben arnya bisa berarti "keadilan prosedural" (procedural dueprocess) dan juga “keadilan substantif” (substantive due process) 20 .

\section{PENUTUP}

Pengaturan Usaha Perasuransian yang dimuat dalam Undang-Undang Nomor 40 Tahun 2014 tentang Perasuransian, serta ditunjuknya Otoritas Jasa

${ }^{20}$ Munir Fuady, ibid, hlm 116 
Keuangan (OJK) sebagai lembaga negara yang memiliki kuasa penuh dalam menjalankan fungsi dan pengawasan meliputi perizinan usaha perasuransian, tata kelola penyelenggaraan perasuransian, pergantian pemilikan, penggabungan dan peleburan, serta sampai pada pembubaran, likuidasi, dan kepailitan dalam dunia perasuransian yang ada di Indonesia, diharapkan dapat membuat kebijakan dalam pengaturan dan pengawasan terhadap perasuransian menjadi lebih berkembang di masa depan dan dapat bersaing dengan negara-negara maju dalam dunia asuransi. Namun tentunya upaya sienergi antara peraturan perundang-undangan yang satu dengan yang lain menjadi kendala secara teknis dan yuridis. Hal tersebut mengingat berdasarkan undang-undang, OJK resmi mengambil alih fungsi pengawasan perbankan dari Bank Indonesia sebagai bank sentral dan pengawasan sektor jasa keuangan non-perbankan dari Badan Pengawas Pasar Modal dan Lembaga Keuangan (Bapepam-LK). Otoritas Jasa Keuangan diharapkan dapat membuat kebijakan pengaturan dan pengawasan terhadap perasuransian yang dapat membawa perasuransian menjadi lebih berkembang di masa depan dan dapat menyaingi negara-negara maju dalam hal asuransi.

Banyak kendala yang dihadapi dalam pelaksanaan pengawasan pengawasan asuransi syariah diantaranya soal pemahaman masyarakat. Kendala lainnya yang cukup berpengaruh adalah dukungan penuh dari para pengambil kebijakan di negeri ini, terutama menteri-menteri dan lembaga pemerintahan yang memiliki wewenang dalam menentukan kebijakan ekonomi. Termasuk kendala dukungan pemerintah adalah upaya harmonisasi dan singkronisasi peraturan yang masih menjadi hambatan secara yuridis diantaranya persoalan. Upaya-upaya dalam mengatasi kendala tersebut dapat dilakukan melalui penguatan struktur. Struktur yang ada saat ini sudah baik, tetapi karena DSN-MUI menghadapi tugas dan tantangan yang lebih berat seperti mengurusi dan bermitra dengan lembaga-lembaga keuangan syariah yang notabene diurus oleh prktisi-praktisi yang professional. Karena itu, mitra kerjanya pun harus bisa mengimbangi secara professional. Disisi lain yang perlu diterjemahkan dalam praktinya sehingga memungkinkan sistem pengawasan berjalan maksimal adalah evaluasi kelembagaan pengawasan harus dijalankan secara keberlanjutan sehingga memungkinkan sistem pengawasan pada lembaga 
e-ISSN : 2621-4105

asusransi syariah utamanya yang dijalankn oleh lembaga Dwan Pengawas syariah dapat berjalan maksimal. Hal yang tidak kalah penting lagi adalah kebutuhan bahwa peraturan harus mengakomodasi kebutuhan yang ada, maka sudah sebaiknya Undang-Undang Nomor 40 Tahun 2014 tentang Perasuransian harus ada penyesuaian. Upaya perubahan tersebut seiring perubahan keadilan subtantif. Hal lain yang penting juga adalah dalam ketentuan Undang-Undang Nomor 14 tahun 2014 kedudukan peraturan tersebut harus mengakomodasi sistem peraturan Otoritas Jasa Keuangan (OJK). Hal ini juga diharapkan peran antara dewan syariah nasional tidak berbenturan dengan peran otoritas jasa keuangan. 


\section{DAFTAR PUSTAKA}

\section{BUKU}

Gemala Dewi,2007, Aspek-Aspek Hukum Dalam Perbankan Dan Perasuransian Syariah Indonesia, Jakarta, Kencana Prenada Media Grup

Sadjipto Rahardjo, 1982, Ilmu Hukum, Alumni, Bandung

Sirajuddin dan Winardi, 2015, Hukum Tata Negara Indonesia, Setara Press (Kelompok Instras Publising), Malang

Sri Rejeki Hartono, 2008. Hukum Asuransi dan Perusahaan Asuransi, Sinar Grafika, Jakarta

Victor M.Situmorang, 2004, Aspek Hukum Pengawasan Melekat, Jakarta: Rineka Cipta

\section{JURNAL}

Bagya Agung Prabowo dan Jasri Bin Jamal, 2016. Peranan Dewan Pengawas Syariah terhadap Praktik Kepatuhan Syariah dalam Perbankan Syariah di Indonesia, Jurnal Hukum Ius Quia Iustum No. 1 Vol. 24 Januari 2017. DOI: https://doi.org/10.20885/iustum.vol24.iss1.art6

Ephin Apriyandanu, Kedudukan Basyarnas Dalam Penanganan Kepailitan Perbankan Syariah Ditinjau Dari UUNo. 21 Tahun 2008 Tentang Perbankan Syariah, Jurnal USM Law Review Vol 1 No 1, Magister Hukum Universitas Semarang, 2018, Semarang.

Suisno, Tinjauan Yuridis Tindak Pelanggaran Usaha Perasuransian Menurut Undang-Undang Nomor 40 Tahun 2014 tentang Perasuransian, Jurnal Independent Vol. 3 No. 1, Universitas Islam Lamongan, 2015, Lamongan. DOI: https://doi.org/10.30736/ji.v3i1.32

\section{INTERNET}

"Kesadaran akan Asuransi Kian Meningkat" http://bisniskeuangan.kompas.com. Kesadaran.Akan.Asuransi.Kian.Meningkat., diakses 11 Oktober 2017, jam 11.11 WIB 